bottom: Srannungen; p. 308, 1. 17 from the bottom: Studes; p. 308, 1. 11 from the bottom: Changein; p. 341 1. 1 from the bottom - indes).

Our remarks here does not change the overall, more than positive estimation of the Author's efforts and of the book, as it sums up conveniently and accurately the decades of individual research and in holistic way depicts a fundamental matter of the early Byzantine history. The oeuvre of Aleksandra Čekalova, as we believe, blazes a trail for the next generations of scholars in discussing the role and the institutional shape of the Roman / Byzantine senate.

Andrzej Kompa, Mirosław J. Leszka

(Łódź)

http://dx.doi.org/10.18778/2084-140X.02.25

\title{
František Čajka, Církevněslovanská legenda o svaté Anastázii [The Church- Slavonic Legend of St. Anastasia], Slovansky ustav AV ČR, Praha 2011, pp. 239 [= Prace Slovanskeho ustavu. Nova řada, svazek 34].
}

The presented study is the sixth title within the Palaeoslavistic ones edited in the series of the Institute of the Slavic Studies to the Academy of Sciences of the Czech Republic. Its author recalls one of these Old-Church-Slavonic literary monuments, which - although known from copies delivered to the scientific circulation, already published and discussed - seem to have their origins undiscovered or, at least, not clear. The life - or legend, as Čajka suggests to state the genre in the title - of St. Anastasia, Early Christian martyr, is preserved in its Latin origin and Greek translation/elaboration, as well as the Slavic version in Russian and Serbian copies from the $14^{\text {th }}-18^{\text {th }}$ cent. Referring to the statements of the past and contemporary scholars occupied in this monument (since the first edition of the Slavic text by A.I. Sobolevskij, also G. Kappel, F. Thomson, E. Bláhová, P.F. Moretti, V. Tkadlčík, D.M. Atanasova, to mention only some of them), Čajka emphasizes the validity of its textological aspect, as the main instrument of the reconstruction of its origins (p. 8). That is why The Church-Slavonic Legend of St Anastasia is not a history of the saint's cult, but a very reliable, philological treatise on the literary monument.

The construction of the study clearly reflects the author's idea of placing The Legend... in a wide context of the Old-Czech literature. The first chapter, Českocírkevněslovanské písemnictví a jeho památky/Czech-Church-Slavonic literary output and its monuments (p. 11-47), is a particu- lar description of a literary production of the Old-Slavonic literature, not only connected to the Czech lands and cultural centres, but also copied in the Slavic East and South. This part of the book presents and discusses literary monuments important not only for the Czech literature, but for the Medieval Middle European literature and culture, as the so-called legends of saints (St. Venceslas, St. Ludmila, St. Vit, St. Apolinarius, St. George and Stephan legends), the Life of St. Benedict, as well as with other well known monuments, like the Evangelium Nicodemi or sermons on Gospel by the pope Gregory the Great and numerous prayers. The author discusses texts arouse and copied in Bohemia, and even copied in Russian or South Slavic territories, written down in Cyrillic and Latin letters; on the grounds of the pope Stephen V's letters, makes inquiries for traces of the Slavonic liturgy in Bohemia. It is worth noting, that Čajka suggests to present not the only one approach to the collected material, but investigates favorable features of both chronological and genological attitudes.

The second part of the study, Legenda o svaté Anastázii/The St Anastasia legend (p. 49-195), is divided, in total, into almost 20 subsections. The first ones are a kind of introduction to the history of the text itself, as Čajka presents the history of the St. Anastasia's cult (part 2.1 Legendární tradice a rozvoj kultu/Legendary tradition and development of the cult, p. 52-58) and both Latin legends originating in the same 
period and other Latin parallels of the legend (parts 2.2 Latinský hagiografický cyklus o svaté Anastázii a Chrysogonovi, latinský text publikovaný G. Kappelem a novè evidované latinské paralely/ The Latin hagiographical cycle of Sts Anastasia and Chrysogonus, a Latin text edited by G. Kappel and recent evidences of Latin parallels, p. 58-61, and 2.8 Kulturněhistorické souvislosti vzniku Anast/Cultural and historical circumstances of the rise of the life, p. 188-195). Like in the cases of other saints (e.g. Paraskeva-Petka), one of the problems is to distinguish the same name characters commemorated in the literary monuments, and such a survey, accompanied by bibliography, is given (p. 52-58). The origins of the text itself seems to be not very obvious. According to the most probably theory, it seems to be a translation of a short Latin version of the legend, made in the $10^{\text {th }}-11^{\text {th }}$ cent. in South-Slavic (Bulgarian) or rather Bohemian environment (p. 201). As part of St. Anastasia's and St. Chrysogonus' relics has been translated to Zadar and venerated in Croatia, and the translation of the Legend is supposed to be made along with St. Chrysogonus' vita, one of most significant conclusions is, that both Saints symbolize a spiritual unity of the Christian East and West (p. 58). In fact, Čajka comes to this conclusion independently of other authors solving the problem of the Legend's origins ${ }^{1}$.

In the textological part, Čajka proves a very strong linguistic competence, and a very good knowledge of both sources, and past and contemporary research and critical studies. The new critical edition of St. Anastasia legend (subchapter 2.4 Edice legendy/The edition of the text, p. 70-87) is prepared on the grounds of ten copies, from which only a few had been introduced into a scientific circulation before this edition (subchapter 2.3 Rukopisná zachování legendy/

1 D. Atanasova, The Slavonic Translation of Latin Vita of St. Anastasia the Widow and Her Companion St. Chrysogonus, SeS, 2007, p. 117-129.
Manuscripts containing the Legend, p. 62-69). An important element of the critical edition is $I n$ dex verborum (subchapter 2.5 , p. 88-124), including Latin parallels of all presented units. The research, made in direction of linguistic and textological investigation, is completed by pointing at collation between the Slavic copies with a Latin version (subchapter 2.6 Textologie/ Textology, p. 125-148), and a detailed revision of the linguistic situation of the text, compared with other Bohemian literary monuments (subchapter 2.7 Jazyková charakteristika Anast/The linguistic characterization of the life, p. 149-187). As a result, a reader gets a complete archaeographical information.

A strong point of the study is, without doubt, the presentation of up to now unknown copies of the Legend and placing them within a grid of already published and investigated ones, which gives a new picture of the history of the Legend and possible ways of its dissemination in Medieval Europe.

The critical study is provided with interesting appendices (the facsimile of correspondence between F. Mareš and V. Tkadlčík and fragments of manuscripts containing the Legend, p. 227-233), list of used abbreviations, and indexes of anthroponyms and toponyms (p. 234-239). The bibliography of a book is really impressive, as includes over 200 Czech, Russian, Bulgarian, Serbian and Croatian, German, French and English studies, old Greek, Latin and Slavic source text editions, and Internet sources, referring not only to the topical monument, but also to the history of the Old-Church-Slavonic language and literature of Cyrillo-Methodian times in general, the Greek-Latin-Slavic literary relations, the Early Slavonic Culture and other humanistic branches. Let's hope that thanks to both English and German summaries, the study crosses the frontiers of a Central Europe and Slavic interest.

Małgorzata Skowronek (tódź) 